\title{
Protein Atonal Homolog 1
}

National Cancer Institute

\section{Source}

National Cancer Institute. Protein Atonal Homolog 1. NCI Thesaurus. Code C111877.

Protein atonal homolog 1 (354 aa, $\sim 38 \mathrm{kDa}$ ) is encoded by the human AT OH1 gene. This protein is involved in the activation of E-box dependent gene expression. 